\title{
Profiles of Birch Sensitization (Bet v 1, Bet $v 2$, and Bet $v$ 4) and Oral Allergy Syndrome Across Italy
}

\author{
Ciprandi G' ${ }^{1}$, Comite $\mathrm{P}^{2}$, Mussap $\mathrm{M}^{2}$, De Amici $\mathrm{M}^{3}$, Quaglini $\mathrm{S}^{4}$, Barocci $\mathrm{F}^{5}$, \\ Marseglia $\mathrm{GL}^{3}$, Scala $\mathrm{E}^{6}$
}

\author{
${ }^{1}$ Allergy Department, IRCCS-AOU San Martino-IST, Genoa, Italy \\ ${ }^{2}$ Laboratory Medicine Department, IRCCS-AOU San Martino, Genoa, Italy \\ ${ }^{3}$ Department of Pediatrics, Foundation IRCCS Policlinico San Matteo, Pavia, Italy \\ ${ }^{4}$ Department of Electrical, Computer and Biomedical Engineering, University of Pavia, Pavia, Italy \\ ${ }^{5}$ Immunohematology and Transfusion Medicine Unit, Rho, Italy, A.O. G. Salvini, Garbagnate Milanese, Italy \\ ${ }^{6}$ Experimental Allergy Unit, IDI-IRCCS, Rome, Italy
}

J Investig Allergol Clin Immunol 2016; Vol. 26(4): 244-248

doi: 10.18176/jiaci.0041

\begin{abstract}
Background: Birch allergy (BA) is a common pollinosis caused by the allergens Bet v 1, Bet v 2, and Bet v 4. Oral allergy syndrome (OAS) is frequently associated with BA. A gradient of sensitization to birch allergen across Europe has been reported. Therefore, this study aimed to investigate the birch sensitization profile, including OAS, across Italy.

Methods: We performed a retrospective study of 854 patients (391 males, mean age 35.9 years, range 18-93 years): 196 patients were recruited in Genoa, 188 in northern Italy, 359 in central Italy, and 111 in southern Italy. Serum IgE to Bet v 1, Bet v 2, and Bet v 4 was assessed, and OAS was analyzed.

Results:With respect to the geographical path Genoa-North-Center-South, the frequency of sensitization to Bet $\mathrm{v} 1$ decreased significantly $(P<.0001)$ from Genoa $(95.41 \%)$ to southern Italy $(58.56 \%)$. The frequency of sensitization to Bet $\mathrm{v} 2$ increased significantly $(P<.0001)$ from Genoa (6.12\%) to southern Italy (52.25\%). The frequency of Bet v 4 also increased significantly $(P=.0002)$ from Genoa (6.12\%) to southern Italy (14.41\%). The distribution of patients with OAS differed significantly across the areas $(P<.0001)$, the most marked difference ranging between $33.5 \%$ in Genoa and $76.9 \%$ in northern Italy. The frequency of birch allergens correlated with OAS in central Italy only. Conclusions: The present study demonstrated a significant difference between sensitization to birch and its clinical expression across Italy. Key words: Bet v 1. Bet v 2. Bet v 4. Oral allergy syndrome. Birch allergy. Serum IgE. Italy.
\end{abstract}

\section{Resumen}

Introducción: El síndrome de alergia oral (SAO) se encuentra frecuentemente asociado a la alergia al polen de abedul. Se han descrito diferentes gradientes de sensibilización a polen de abedul en Europa. Este estudio pretende determinar el perfil de sensibilización a polen de abedul, incluyendo la presencia de SAO, en Italia.

Métodos: Estudio retrospectivo con 854 pacientes (391 hombres, edad media 35,9 años, rango 18-93 años): 196 pacientes procedían de Génova, 188 del Norte de Italia, 359 de Italia Central y 111 del Sur de Italia. Se determinó la IgE específica a Bet v 1, Bet v 2 y Bet v 4, así como la presencia de SAO.

Resultados: De acuerdo a la procedencia geográfica Génova-Norte-Centro-Sur de Italia, la sensibilización a Bet $v 1$ disminuye significativamente $(P<0,0001)$ desde Génova $(95,41 \%)$ hasta el Sur de Italia $(58,56 \%)$. La sensibilización a Bet v 2 aumenta significativamente $(P<0,0001)$ desde Génova $(6,12 \%)$ hasta el Sur de Italia (52,25\%). También la sensibilización a Bet v 4 aumenta significativamente $(P<0,0002)$ desde Génova $(6,12 \%)$ hasta el Sur de Italia (14,41\%). Existe una distribución del SAO significativamente diferente entre las diferentes áreas geográficas consideradas, siendo la máxima diferencia la presentada entre Génova (33,5\%) y el Norte de Italia (76,9\%). Las frecuencias de sensibilización a las diferentes moléculas del polen de abedul se correlacionan con el SAO solo en la región Central de Italia. Conclusiones: El presente estudio demuestra la existencia de diferencias significativas entre la sensibilización a las diferentes moléculas del polen de abedul y su expresión clínica en diferentes regiones italianas.

Palabras clave: Bet v 1. Bet v 2. Bet v 4. Síndrome de alergia oral. Alergia a polen de abedul. IgE sérica. Italia. 


\section{Introduction}

$\operatorname{IgE}$ is the hallmark of allergy $[1,2]$. Birch allergy (BA) is one of the most frequent types of pollinosis in Europe [3-5]. At present, $\mathrm{BA}$ is characterized by the IgE response to Betula verrucosa pollen allergens. Birch tree belongs to the Fagales order, which encompasses 8 families, including Betulaceae. The Betulaceae family can in turn be divided into Betuloideae (the main genus of birch and alder) and Coryloideae (the main genus of hazel, hornbeam, and hop-hornbeam).

Of the several birch allergens that have recently been identified, the main molecules are Bet $\mathrm{v} 1$, Bet $\mathrm{v} 2$, and Bet $\mathrm{v} 4$. The major birch pollen allergen is Bet $\mathrm{v} 1$, which is a pathogenesis-related 10 (PR-10) protein. Bet $v 1$ shares molecular homology with many plants of the Betulaceae family [6]. Oral allergy syndrome (OAS) is a common allergic disorder caused by a pollen-fruit cross-reaction and is very common in BA patients, with an average prevalence of 70\% [7-11]. The most frequent fruits causing OAS in BA patients belong to the Rosaceae family, which includes pome fruits (mainly apple) and hazelnut $[7,8]$. Interestingly, it has been proposed that BA-associated OAS may depend on the molecular homology between the Bet $\mathrm{v} 1$ of Betulaceae family pollens and the Bet $\mathrm{v} 1$ homologs of hazelnut (Cor a 1) or of Rosaceae fruits, including apple, peach, pear, apricot, and cherry $[12,13]$. Bet v 2 is a profilin that is able to bind to actin and thus regulate cell division, growth, and differentiation [14]. Given their high sequence conservation, profilins are widely cross-reactive, and reactions have been reported between pollen and food and between pollen and latex [15]. The widespread cross-reactivity of profilins has led to the designation of profilins as panallergens [16]. A specific family, the so-called Bet v 2 family, has been defined [17]. Bet $\mathrm{v} 4$ is a polcalcin, ie, a calcium-binding protein. Bet $\mathrm{v} 4$ has been also considered a panallergenic molecule [18].

An intriguing gradient of sensitization across Europe has been reported: Bet $\mathrm{v} 1$ is predominant in northern Europe, whereas Bet $\mathrm{v} 2$ and Bet $\mathrm{v} 4$ are more relevant in southern Europe [19-22]. Therefore, this study aimed to evaluate the profile of sensitization to birch allergen molecules in a large sample of allergic patients in Italy by taking into consideration the geographic area and the presence of associated OAS.

\section{Materials and Methods}

We performed a retrospective study of 854 patients (391 males, mean age 35.9 years, range 18-93), who were referred to the allergy departments of various hospitals for suspected allergic rhinitis between 2011 and 2014. Recruitment was as follows: Genoa, 196 patients; northern Italy, 188 patients; central Italy, 359 patients; and southern Italy, 111 patients. The inclusion criteria were sensitization to birch, as documented by skin prick test positivity and/or serum allergenspecific $\operatorname{IgE}>0.35 \mathrm{kU}_{\mathrm{A}} / \mathrm{L}$, and nasal symptoms consistent with pollen exposure. The local ethics committee approved the study, and all patients signed an informed consent form.
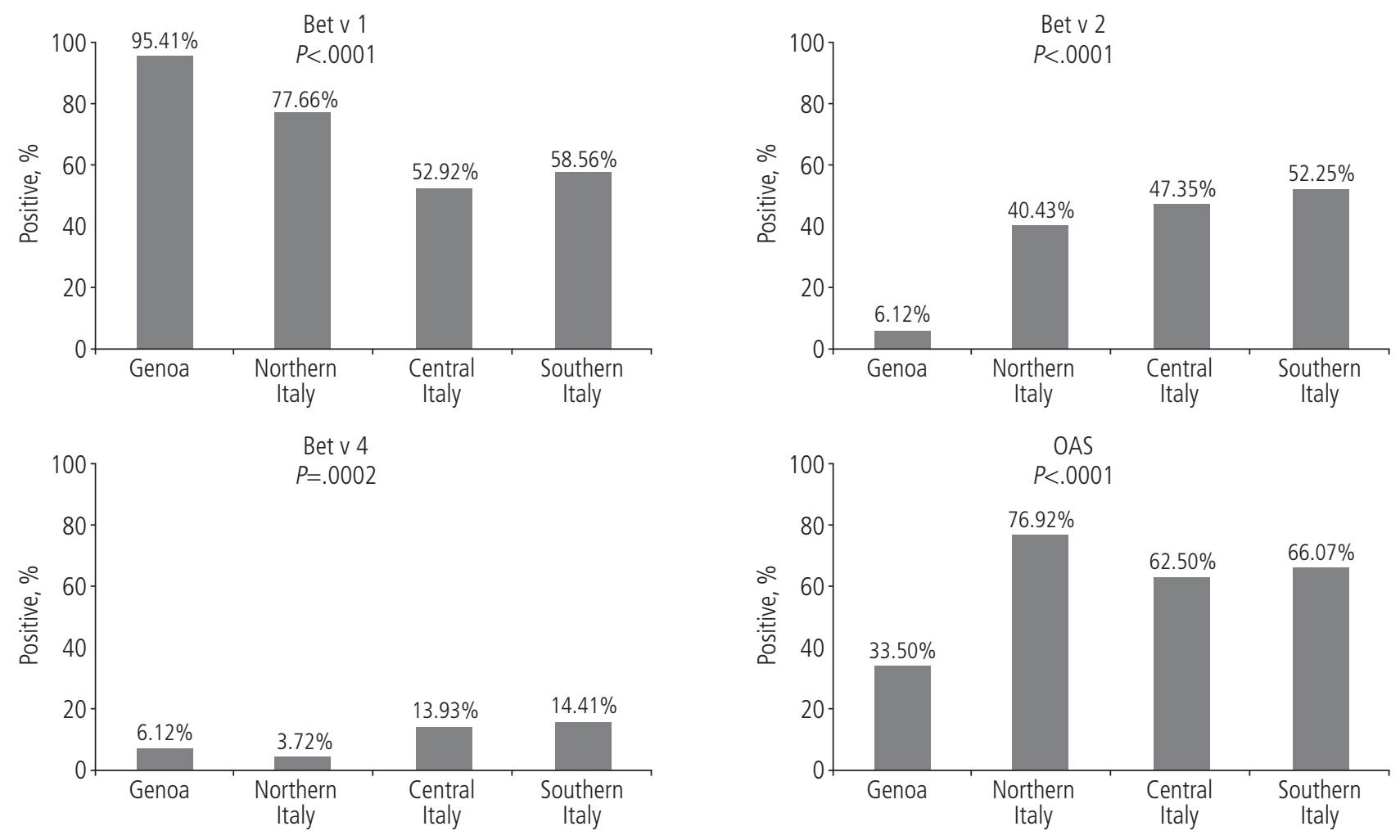

Figure 1. Percentages of patients sensitized to Bet v 1, Bet v 2, and Bet v 4 in 4 areas of Italy, and percentages of patients with oral allergy syndrome (OAS) in these areas. 
The presence of OAS was assessed based on a history of oropharyngeal itching immediately after eating any type of fresh fruits or vegetables related to Bet v 1 allergens, as reported elsewhere $[13,14,16]$.

\section{Serum IgE Assay}

Serum levels of specific IgE were detected using ImmunoCAP (Thermo Fisher Scientific) in peripheral blood samples. Serum was collected in gel separator tubes, centrifuged, and stored at $-20^{\circ} \mathrm{C}$ until determination of Bet $\mathrm{v} 1$.

Circulating specific IgE antibodies were measured according to the manufacturer's instructions [23]. Specific IgE concentrations were expressed in $\mathrm{kU}_{\mathrm{A}} / \mathrm{L}$ based on the traceable calibration to the $2^{\text {nd }} \mathrm{WHO}$ International Reference Preparation for Human IgE, and the cutoff was set at $0.35 \mathrm{kU}_{\mathrm{A}} / \mathrm{L}$ [24].

\section{Statistical Analysis}

The statistical analysis was performed using the statistical software package Medcalc 9 (Frank Schoonjans, BE). All the variables were dichotomized (positive/negative, present/absent), and prevalence was reported as a percentage. We used the chisquare test to investigate associations between the different areas and the association the between a positive combination of allergens and OAS. A $P$ value $<.05$ was considered statistically significant. The odds ratio was used to estimate the risk of developing OAS in patients who were positive to allergens.

\section{Results}

Figure 1 shows the frequencies of sensitizations for Bet $v 1$, Bet $\mathrm{v} 2$, and Bet $\mathrm{v} 4$ and the percentage of patients with OAS in the 4 geographical areas evaluated.

With respect to Bet $\mathrm{v} 1$, a significant decreasing percentage of sensitized patients was observed between Genoa (95.41\%)

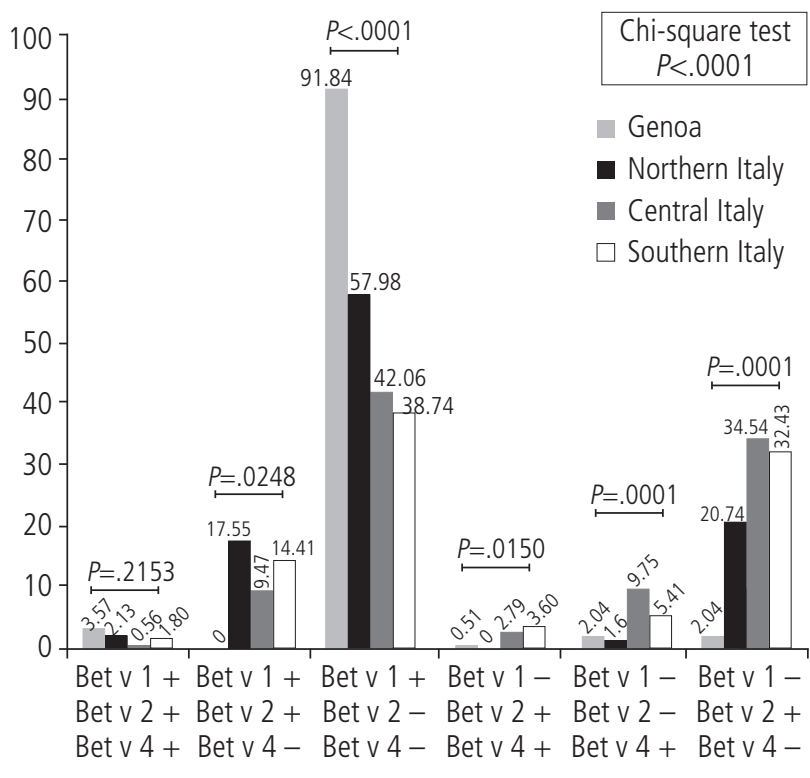

Figure 2. Percentages of patients with different patterns of sensitization to Bet $v 1$, Bet $v 2$, and Bet $v 4$ in 4 areas of Italy.
Table 1. Percentages of Patients Sensitized to Pollens Other Than Birch and Percentages of the Most Frequent Fruits Causing OAS in the 4 Geographical Areas

\begin{tabular}{lcccc}
\hline & Genoa & $\begin{array}{c}\text { Northern } \\
\text { Italy }\end{array}$ & $\begin{array}{c}\text { Central } \\
\text { Italy }\end{array}$ & $\begin{array}{c}\text { Southern } \\
\text { Italy }\end{array}$ \\
\hline Par j 2 & & 17.7 & 26.7 & 35.8 \\
Ole e1 & 27.9 & 25.9 & 27 & 30.7 \\
Phl p 1+ Phl p 5 & 27.3 & 52.4 & 55.5 & 44.6 \\
Cup a 1 & 6.7 & 4.1 & 3.7 & 5.4 \\
Amb a 1 & 1.4 & 7.4 & 5.4 & 5.8 \\
Apple & 83 & 68 & 55 & 53 \\
Peach & 41.5 & 28 & 22 & 24 \\
Apricot & 17 & 16 & 14 & 17 \\
Cherry & 15 & 10 & 12 & 13 \\
\hline
\end{tabular}

and southern Italy $(58.56 \%)(P<.0001)$. In the case of Bet $\mathrm{v} 2$, a significant increasing percentage of sensitized patients was observed from Genoa $(6.12 \%)$ to southern Italy $(52.25 \%)$ $(P<.0001)$. As for Bet $\mathrm{v} 4$, a significant increasing percentage of sensitized patients was observed from Genoa (6.12\%) to southern Italy $(14.41 \%)(P=.0002)$.

In the case of OAS, the distribution of OAS-positive patients differed significantly across the geographical areas, the most marked difference being between Genoa (33.5\%) and northern Italy $(76.9 \%)(P<.0001)$.

The results of the analysis of sensitization profiles are shown in Figure 2. Significant differences were observed for the various patterns $(P<.0001)$ and geographical areas $(P$ values ranging from 0.2 to $<.0001$ ). In particular, the most frequent pattern was Bet v 1-positive, Bet v 2- and Bet v 4-negative, which was more evident in Genoa. In contrast, sensitization to Bet $\mathrm{v} 2$ and Bet $\mathrm{v} 4$ was only rare in Genoa, but relatively frequent in other areas $(P<.0001$ for both).

The association between a positive combination of allergens and presence/absence of OAS was significant for only 2 combinations of allergens: Bet $\mathrm{v} 1$ and Bet $\mathrm{v} 2$ positive, Bet $\mathrm{v} 4$ negative $(P<.0001)$; and Bet $\mathrm{v} 1$ and Bet $\mathrm{v} 4$-positive, Bet $\mathrm{v} 2$-negative $(P=.0033)$. When the sample as a whole was taken into consideration and patients divided according to positivity or negativity to allergens, the odds ratios showed an increased risk of OAS for patients who were positive to recombinant allergens. When the different geographical areas were taken into consideration, the odds ratios did not show a significant risk, except for Bet $\mathrm{v} 2(\mathrm{OR}=1.5591, P=.0390)$ and Bet $v 4(\mathrm{OR}=0.3455, \mathrm{P}=.0006)$ for central Italy.

The profiles of the sensitizing pollens are reported after taking into account the geographical areas of the fruits that most frequently cause OAS (Table).

\section{Discussion}

Allergy to Betulaceae pollen is one of the most common types of pollinosis in our geographic area [20]. Bet $\mathrm{v} 1$ is the major birch pollen allergen. The clinical relevance of Bet $\mathrm{v} 1$ is supported by evidence that more than $95 \%$ of patients living in Northern Europe 
and who are allergic to birch are sensitized to Bet $v 1$. Therefore, routine diagnosis and therapy of Betulaceae pollen-allergic patients is generally based on the assessment of Bet v 1 [25] However, 2 other allergens related to birch, Bet v 2 and Bet $v 4$, are also evaluated in clinical practice. Both are panallergens that should be taken into consideration when confirming a diagnosis of BA and, especially, when prescribing allergen immunotherapy.

It is also noteworthy that sensitization to Bet $\mathrm{v} 1$ can occur in the absence of the natural source of Bet v 1 (eg, birch trees), as in the report of sensitization to Bet $\mathrm{v} 1$ in patients living in a birch-free area of central Italy [21]. This phenomenon may explain why Bet v 1 affects patients with coreactivity to the order Fagales, which includes birch, hazel, hornbeam, hophornbeam, and oak [26].

OAS is frequently associated with BA. However, the management of OAS remains controversial, mainly with respect to the role of molecular diagnosis [27]. In this regard, sensitization to Bet $\mathrm{v} 1$ has been shown to be frequently associated with OAS in patients with pollen allergy [28]. In addition, application of microarray for measurement of PR-10 proteins was a reliable approach in the diagnosis of apple-induced OAS in patients with birch pollen allergy [29]. OAS associated with BA may depend on cross-reactivity between Betulaceae pollen allergens and structurally homologous food proteins. Bet $\mathrm{v} 1$ in particular cross-reacts with several of the proteins in Rosaceae fruits, such as apple (Mal d 1), hazelnut (Cor a 1), pear (Pyr c 1), apricot (Pru ar 1), and cherry (Pru av 1) [30]. Therefore, a molecular diagnostics approach based on birch allergens could prove useful in the allergy workup.

The first part of the present study showed a significant gradient of sensitization across Italy for all birch allergens, thus confirming findings from previous studies [19-22]. The findings for Genoa in particular, in terms of both sensitization profile and prevalence of OAS, are surprising. Patients living in Genoa show the highest percentage of Bet $\mathrm{v} 1$ positivity and the lowest percentage of both Bet $\mathrm{v} 2$ and Bet $\mathrm{v} 4$ sensitization and OAS. This result could be explained by the characteristics of the flora in the Genoa area. In fact, Genoa could be considered a birch-free area, although hop-hornbeam (Ostrya carpinifolia), which belongs to the Betulaceae family, is relatively common. In this regard, the pollen count for hophornbeam was relevant in Genoa during March-April. The allergen of hop-hornbeam, Ost c 1, is a Bet v 1-homologous protein [31]. In particular, on the basis of IgE-binding experiments, it has been speculated that allergy to Fagales allergens may be initiated by independent sensitization to a specific member of the Betuloideae or Coryloideae family [32]. Furthermore, cross-reactivity could progress to Bet v 1-homologous proteins. Therefore, the allergenic characteristics of Ost c 1, which are similar to those of Bet v 1 , could explain the low percentage of OAS-positive patients in our area. Wallner et al [33] compared Italian patients living in a birch-free area with Austrian patients exposed to Bet v 1 and found a different sensitization pattern for each population [33]. These outcomes suggest that Bet $\mathrm{v} 1$ could be one of the allergenic proteins present in Ostrya pollen and that it could be responsible for subsequent potential cross-reactivity with other members of taxonomically related families, including pollens and fruits. However, Ost c 1 could be responsible for primary sensitization, which induced respiratory symptoms.
In addition, Fagales tree pollens show $>70 \%$ sequence identity with Bet v 1, although similarities to homologs from typical birch pollen-related fruits and vegetables are much lower [34]. Cross-reactive Bet v 1 homologs share only $37 \%$ to $67 \%$ of their sequences with Bet v 1 [35].

Our results also underline the relevance of the sensitization profile in OAS. Analysis of the sensitization profile revealed differences in the prevalence of OAS, a finding that is consistent with differences in exposure to pollens across Italy. Sensitization to Bet v 2, in particular, is a significant risk factor for having OAS in central Italy.

We considered the profiles of sensitization to other pollens and fruits as the cause of OAS according to geographical area and found differences that may depend on climate. However, this issue warrants further investigation in more in-depth studies.

Our study is subject to a series of limitations. It is retrospective and cross-sectional and did not take into consideration the profile of sensitization to the most relevant food allergens. Further investigations should address these issues. Moreover, sensitization to Bet v 1 could overlap with sensitization to profilin in patients with food-induced OAS Again, this issue should be extensively investigated in an appropriately designed study.

In conclusion, the present study demonstrated a significant difference in sensitization to birch allergens and associated clinical expression across Italy.

\section{Acknowledgments}

The authors wish to thank Cristina Torre (Pediatric Clinic, Fondazione IRCCS San Matteo, Pavia, Italy), Sabrina Nigrisoli, and Giorgia Testa (Pediatric Clinic, Fondazione IRCCS San Matteo, Pavia, Italy) for their outstanding technical support.

\section{Funding}

The authors declare that no funding was received for the present study.

\section{Conflicts of Interest}

The authors declare that they have no conflicts of interest.

\section{References}

1. Wheatley LM, Togias A. Allergic rhinitis. New Engl J Med. 2015;172:456-63

2. Barnes PJ. Pathophysiology of allergic inflammation. Immunol Rev. 2011;242:31-50.

3. D'Amato G, Cecchi L, Bonini S, Nunes C, Annesi-Maesano I, Behrendt $\mathrm{H}$, Liccardi G, Popov T, van Cauwenberge P. Allergenic pollen and pollen allergy in Europe. Allergy. 2007;62:976-90.

4. Stevens WJ, Ebo DG, Hagendorens MM, Bridts $\mathrm{CH}$, De Clerck LS. Is the prevalence of specific IgE to classical inhalant aeroallergens among patients with respiratory allergy changing? Evidence from two surveys 15 years apart. Acta Clin Belg. 2003;58:178-82.

5. Negrini AC, Negrini S, Giunta V, Quaglini S, Ciprandi G. Thirty year survey on airborne pollen concentrations in Genoa (Italy): relationship with sensitizations, meteorological data, and air pollution. Am J Rhinol Allergy. 2011;25:232-41. 
6. Jensen-Jarolim E. Happy 25th birthday, Bet v 1 ! WAO Journal. 2014;7:14-7.

7. Bohle B. The impact of pollen-related food allergens on pollen allergy. Allergy. 2007;62:3-10.

8. Webber CM, England RW. Oral allergy syndrome: a clinical, diagnostic, and therapeutic challenge. Ann Allergy Asthma Immunol. 2010;104:101-8.

9. Eriksson NE, Formgren $H$, Svenonius E. Food hypersensitivity in patients with pollen allergy. Allergy. 1982;37:437-43.

10. Katelaris $\mathrm{CH}$. Food allergy and oral allergy or pollen-food syndrome. Curr Opin Allergy Clin Immunol. 2010;10:246-51.

11. Vieths S, Scheurer S, Ballmer-Weber B. Current understanding of cross-reactivity of food allergens and pollens. Ann N Y Acad Sci. 2002;964:47-68.

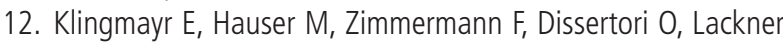
P, Wopfner N, Ferreira F, Wallner M. Identification of B-cell epitopes of Bet $v 1$ involved in cross-reactivity with food allergens. Allergy. 2009;64:647-51.

13. Kollmann D, Geroldinger-Simic M, Kinaciyan T, Huber $H$, Ebner C, Lidholm J, Bohle B. Recombinant Mal d 1 is a reliable diagnostic tool for birch pollen allergen-associated apple allergy. J Allergy Clin Immunol. 2013;1321008-10.

14. Valenta $R$, Ferreira $F$, Grote $M$. Identification of profilin as an actin-binding protein in higher plants. J Biol Chem. 1993;268:23777-81.

15. Hauser M, Roulias A, Ferreira F, Egger M. Panallergens and their impact on the allergic patient. Allergy Asthma Clin Immunol. 2010;6:1-14.

16. Asero R, Mistrello G, Roncarolo D, Amato S, Zanoni D, Barocci F, Caldironi G. Detection of clinical markers of sensitization to profilin in patients allergic to plant-derived foods. J Allergy Clin Immunol. 2003;112:427-32.

17. Jimenez-Lopez JC, Morales S, Castro AJ, Volkmann D, Rodríguez-García MI, Alché JD. Characterization of profilin polymorphism in pollen with a focus on multifunctionality. PLoS One. 2012;7(2):e30878.

18. Engel E, Richter K, Obermeyer G. Immunological and biological properties of Bet $v 4$, a novel birch pollen allergen with two EF-hand calcium-binding domains. J Biol Chem. 1997;272:28630-7.

19. Moverare R, Westritschning $K$, Svensson $M$, Hayek $B$, Bende M, Pauli G, Sorva R, Haahtela T, Valenta R, Elfman L. Different $\lg \mathrm{E}$ reactivity profiles in birch pollen-sensitive patients from six European populations revealed by recombinant allergens: an imprint of local sensitization. Int Arch Allergy Immunol. 2002;128:325-35.

20. Rossi RE, Monasterolo G, Monasterolo S. Detection of specific IgE antibodies in the sera of patients allergic to birch pollen using recombinant allergens Bet v 1, Bet v 2, Bet v 4: evaluation of different lgE reactivity profiles. Allergy. 2003;55:929-32.

21. Mari $A$, Wallner $M$, Ferreira F. Fagales pollen sensitization in a birch-free area: a respiratory cohort survey using Fagales pollen extracts and birch recombinant allergens. Clin Exp Allergy. 2003;33:1419-28.

22. Sekerkova A, Polackova M. Detection of Bet v 1, Bet $v 2$ and Bet $v 4$ specific $\lg \mathrm{E}$ antibodies in the sera of children and adult patients allergic to birch pollen: evaluation of different lgE reactivity profiles depending on age and local sensitization. Int Arch Allergy Immunol. 2011;154:278-85.

23. Leimgruber $A$, Mosimann $B$, Claeys $M$, Seppey $M$, Jaccard $Y$, Aubert $V$, Peitrequin R, Nisoli MP, Pécoud A. Clinical evaluation of a new in-vitro assay for specific lgE, the immuno CAP system. Clin Exp Allergy. 1991;21:127-31.

24. Seagroatt $V$, Anderson SG. The second international reference preparation for human serum immunoglobulin $\mathrm{E}$ and the first British standard for human serum immunoglobulin E. J Biol Stand. 1981;9:431-7.

25. Mari A. Multiple pollen sensitization: a molecular approach to the diagnosis. Int Arch Allergy Immunol. 2001;125:57-65.

26. Niederberger $V$, Pauli G, Gronlund $H$. Recombinant birch pollen allergens ( $r$ Bet $\vee 1$ and $r$ Bet $\vee$ 2) contain most of the $\lg$ E epitopes present in birch, alder, hornbeam, hazel, and oak pollen: a quantitative IgE inhibition study with sera from different populations. J Allergy Clin Immunol. 1998;102:57991.

27. Ma S, Sicherer SH, Nowak-Wegrzyn A. A survey on the management of pollen-food allergy syndrome in allergy practices. J Allergy Clin Immunol. 2003;112:84-8.

28. Turner PJ, Dawson TC, Skypala IJ, FoxAT. Management of pollen food and oral allergy syndrome by health care professionals in the United Kingdom. Ann Allergy Asthma Immunol. 2015;114(5):427-8.e1. doi: 10.1016/j.anai.2015.02.011.

29. Thomson JC, Kroker GF. The role of component-resolved testing in food allergy and oral allergy syndrome. Ann Allergy Asthma Immunol. 2010;104:543.

30. Ebo DG, Bridts CH, Verweij MM, De Knop KJ, Hagendorens MM, De Clerck LS, Stevens WJ. Sensitization profiles in birch pollen-allergic patients with and without oral allergy syndrome to apple: lessons from multiplexed componentresolved allergy diagnosis. Clin Exp Allergy. 2010;40:339-47.

31. Patriarca $S$, Voltolini $S$, Navone $R$, Martini $S$, Montanari C, Negrini A, Troise C. Biochemical and immunochemical characterization of hop-hornbeam (Ostrya Carpinifolia Scop.) pollen. Aerobiologia. 2000;16:255-60.

32. Hauser M, Asam C, Himly M, Palazzo P, Voltolini S, Montanari C, Briza P, Bernardi ML, Mari A, Ferreira F, Wallner M. Bet v 1-like pollen allergens of multiple Fagales species can sensitize atopic individuals. Clin Exp Allergy. 2011;41.1804-14.

33. Wallner M, Erler A, Hauser M, Klinglmayr E, Gadermaier $G$, Vogel L, Mari A, Bohle B, Briza P, Ferreira F. Immunologic characterization of isoforms of Car b 1 and Que a 1, the major hornbeam and oak pollen allergens. Allergy. 2009;64:452-60.

34. Radauer $\mathrm{C}$, Breiteneder $\mathrm{H}$. Pollen allergens are restricted to few protein families and show distinct patterns of species distrtibution. J Allergy Clin Immunol. 2006;117:141-7.

35. Jenkins JA, Griffiths-Jones S, Shewry PR, Breiteneder H, Mills EN. Structural relatedness of plant food allergenes with specific references to cross-reactive allergens: an in silico analysis. J Allergy Clin Immunol. 2005;115:163-70.

- Manuscript received July 24, 2015; accepted for publication October 21, 2015.

\section{Giorgio Ciprandi}

Largo R. Benzi 10

16132 Genoa, Italy

E-mail gio.cip@libero.it 